\title{
Findings of Phyllosoma Larvae and Nistos of the Family Scyllaridae (Crustacea, Decapoda) in the Southern Mediterranean Sea
}

\author{
E. Pagliarino ${ }^{1, \mathrm{a}}$, D. Massi ${ }^{2}$, E. Canali ${ }^{3}$, C. Costa $^{3, *}$, D. Pessani ${ }^{4}$ and M.L. Bianchini ${ }^{1, \mathrm{~b}}$ \\ ${ }^{1}$ Ist. Biologia Agroambientale e Forestale, Italian National Research Council, IBAF CNR \\ ${ }^{a}$ Villa Paolina, Via Guglielmo Marconi 2, 05010 Porano TR, Italy \\ ${ }^{b}$ Via Salaria km 29.300, 00015 Monterotondo Scalo RM, Italy \\ ${ }^{2}$ Ist. Ambiente Marino e Costiero, Italian National Research Council, IAMC CNR, Via L. Vaccara 61, 91026 Mazara del \\ Vallo TP, Italy \\ ${ }^{3}$ Consiglio per la Ricerca e la sperimentazione in Agricoltura, Unità di ricerca per l'ingegneria agraria, Via della \\ Pascolare 16, 00015 Monterotondo Scalo RM, Italy \\ ${ }^{4}$ Lab. Zoologia e Biologia Marina, Dip. Biologia Animale e dell'Uomo, Università degli Studi di Torino, Via Accademia \\ Albertina 13, 10123 Torino, Italy
}

\begin{abstract}
The rare findings of specimens in larval or post-larval stages (6 phyllosomas and 7 nistos/early juveniles) belonging to the family Scyllaridae are reported for the waters around Sicily. Some were stranded on different winter occasions near the Strait of Messina (north-eastern Sicily), while others were collected during experimental trawl surveys carried out in the Sicilian Channel, at depths up to $450 \mathrm{~m}$. All phyllosoma instars were in advanced stages of development; however, the absence of complete morphological references on the larval characteristics of the family Scyllaridae, necessary for distinguishing the different genera (Scyllarus and Scyllarides, small or large slipper lobsters, or the extremely rare Acantharctus) and species inhabiting the Mediterranean, did not allow to attribute the phyllosomas to a specific taxon. On the contrary, apart from one nisto without apparent lobes (maybe belonging to the species Scyllarides latus), nistos/early juveniles could be classified at generic level on the basis of similarities with the morphology of adult antennae, as pertaining to the genus Scyllarus, but the characters of juveniles are in general ineffective to discriminate between Scyllarus arctus and Scyllarus pygmaeus (the only two known Central Mediterranean species); in fact, the small size and the depth at which they settled suggested that some may belong to the smaller, deeper species Scyllarus pygmaeus.
\end{abstract}

Keywords: Scyllaridae, Scyllarus sp., slipper lobster, phyllosoma, nisto, Mediterranean Sea.

\section{INTRODUCTION}

The family Scyllaridae is present in the Mediterranean with five species [1]: mainly Scyllarides latus (Latreille, 1802), of commercial importance [2], and the small Scyllarus arctus (Linnaeus, 1758); the less common Scyllarus pygmaeus (Bate, 1888) [3]; the very rare Scyllarus caparti Holtuis, 1952 [4] and Acantharctus posteli (Forest, 1963) [5].

The phyllosomas of the slipper lobsters are planktonic with transparent, leaf-like shape [6] and with a life span of a few months $[7,8]$; they pass through at least 9-12 instars, depending on the scale used, and are often not ascribable to any "adult" specific type [9]. The last phyllosoma instar settles as nisto (a.k.a. pseudibacus), similar to the adult. In the central Mediterranean, references to the larval findings

*Address correspondence to this author at the Consiglio per la Ricerca e la sperimentazione in Agricoltura, Unità di ricerca per l'ingegneria agraria.

Via della Pascolare 16, 00015 Monterotondo Scalo RM, Italy;

Tel: 0039-06-90675214; Fax: 0039-06- 90625591;

E-mail corrado.costa@entecra.it and to their local geographical distribution are few and mainly old $[10,11]$. While early phyllosomas (instar I) of the Mediterranean species can be determined by the identification key of Pessani and Mura [12], and later instars might possibly be screened following Rivera and Mujica [13] and Pessani and Mura [12], nistos and juveniles, only very rarely caught [14], could be classified on the basis of similarities between juveniles and adults [15]; moreover, generally nistos present setolose pleopods, while pleopods of early juveniles are shovel-shaped [16].

This paper reports some rare findings of larval and early post-larval individuals of the family Scyllaridae in the waters around Sicily, describes the main features of the specimens, and attempts their taxonomic attribution.

\section{MATERIALS AND METHODS}

Five specimens, of which 4 phyllosomas, were found stranded in different occasions on the beach of Cape Faro (Strait of Messina, north-eastern Sicily) in the winter months of 1995 and 1996. Eight other specimens, of which 2 phyllosomas, were collected during GRUND trawl surveys 


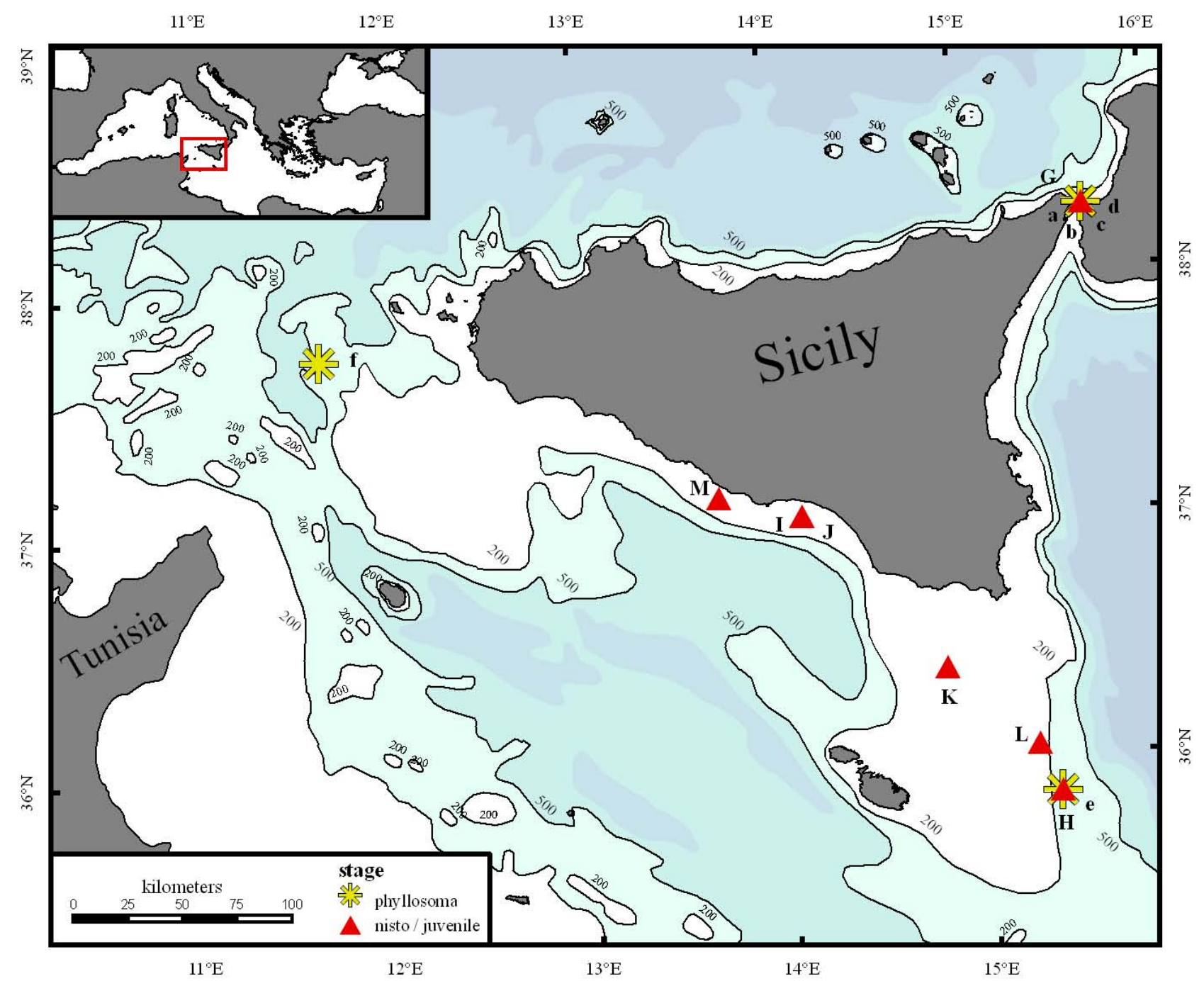

Fig. (1). The study area, with the locations where phyllosomas and nistos/early juveniles of Scyllaridae species were collected (individual letter codes as in Table 1).

carried out in the autumn of 2003 (hauls D086 and C088), in the spring and autumn of 2004 (hauls A072 and C085), in the autumn of 2005 (haul A045) and in the autumn of 2006 (the very-deep haul D023) in the Sicilian Channel (Fig. 1). All specimens were measured and photographed, but only the most recently collected individuals were preserved; the phyllosomas c and e were also drawn. The measurements (in $\mathrm{mm}$ ) included: for the phyllosomas, total length (TL, from the anterior margin of the cephalic shield between the eyes to the posterior tip of the abdomen), eye length (EL), cephalic shield length (CSL) and width (CSW), thorax width (TW); for nistos and juveniles, total length (TL), carapace length (CL) and width (CW).

\section{RESULTS AND DISCUSSION}

The stranding/haul specifications and the phyllosomas/early juveniles retrieved in each location are reported in Table 1; the pictures of captured nistos/early juveniles are shown in Fig. (2).

Three stranded phyllosomas had similar morphological characteristics, with the two specimens stranded in January (a) and February (b) being almost of the same size $(29 \mathrm{~mm}$ TL and $31 \mathrm{~mm}$ TL, respectively); As a matter of fact these two presented slightly different features from the other individual, suggesting an earlier stage of development. The third one (c), collected in March, was very large (44 mm $\mathrm{TL}$ ), both when compared with the other local findings and with the lengths reviewed by Pessani and Mura [12] for the instars of Scyllarus arctus (max TL: $28.0 \mathrm{~mm},[10] ; 26.5$ $\mathrm{mm},[11] ; 24.5 \mathrm{~mm},[17] ; 18.5 \mathrm{~mm}$, Pessani and Mura unpublished); it is thus possible to infer that it was an advanced phyllosoma instar of Scyllarides latus. One more specimen (d) was lost after retrieving. The stranded nisto $(G$, $27 \mathrm{~mm}$ TL), maybe just an exuvia, was in bad condition, having lost almost all limbs; its antennae showed 5 lobes, and it should have belonged to the genus Scyllarus.

One smaller phyllosoma instar (E, $18 \mathrm{~mm}$ TL) and one nisto $(\mathrm{H}, 19 \mathrm{~mm} \mathrm{TL})$ without evident pigmentation (probably still in the natant phase) were caught in 2003 in the same haul (D086) between $280 \mathrm{~m}$ and $300 \mathrm{~m}$ depth on muddy bottom characterized by the facies of the anthozoan Funiculina quadrangularis (Pallas, 1766); during the same 


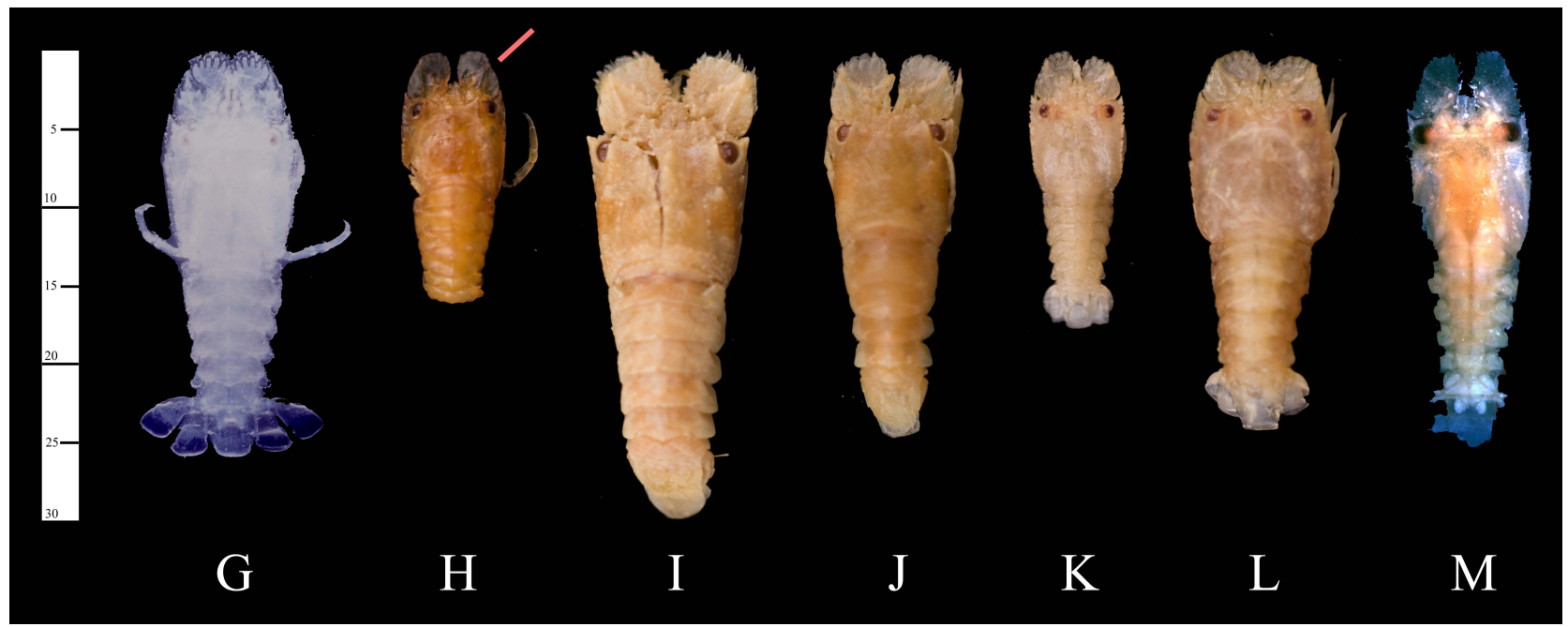

Fig. (2). The nistos/early juveniles of Scyllaridae species collected in Sicilian waters (individual letter codes as in Table 1). All could be ascribed to the genus Scyllarus, with the only possible exception of specimen H [broken tail; line pointing to the antennal margin], which might belong to the species Scyllarides latus.

Table 1. Main Information on Phyllosoma Larvae and Nisto/Early Juveniles Collected in the Waters Around Sicily

\begin{tabular}{|c|c|c|c|c|c|}
\hline Specimen & Date & Location (Average) & Stage & TL $(\mathbf{m m})$ & Remarks \\
\hline a & $14 / 01 / 1995$ & Strait of Messina - Cape Faro & phyllosoma & 29 & stranded \\
\hline $\mathrm{b}$ & 03/02/1996 & Strait of Messina - Cape Faro & phyllosoma & 31 & stranded \\
\hline $\mathrm{c}$ & $12 / 03 / 1996$ & Strait of Messina - Cape Faro & phyllosoma & 44 & stranded \\
\hline $\mathrm{d}$ & $12 / 03 / 1996$ & Strait of Messina - Cape Faro & phyllosoma & n.a. & stranded \\
\hline $\mathrm{e}$ & $\begin{array}{c}04 / 10 / 2003 \\
13: 45\end{array}$ & $\begin{array}{c}\text { Sicilian Channel - Maltese Bank } \\
\varphi \mathrm{N} 35^{\circ} 51^{\prime} .18 ; \lambda \mathrm{E} 15^{\circ} 21^{\prime} .53 \text { (\#86) }\end{array}$ & phyllosoma & 16 & $280-300 \mathrm{~m}$ \\
\hline $\mathrm{f}$ & $\begin{array}{c}18 / 11 / 2006 \\
16: 30\end{array}$ & $\begin{array}{c}\text { West of Egadi Islands } \\
\varphi \mathrm{N} 37^{\circ} 44^{\prime} .96 ; \lambda \mathrm{E} 11^{\circ} 38^{\prime} .77 \text { (\#23) }\end{array}$ & phyllosoma & 19 & $430-500 \mathrm{~m}$ \\
\hline G & 02/03/1996 & Strait of Messina - Cape Faro & nisto, exuvia & 27 & stranded \\
\hline $\mathrm{H}$ & $\begin{array}{c}04 / 10 / 2003 \\
13: 45\end{array}$ & $\begin{array}{c}\text { Sicilian Channel - Maltese Bank } \\
\varphi \mathrm{N} 35^{\circ} 51^{\prime} .18 ; \lambda \mathrm{E} 15^{\circ} 21^{\prime} .53 \text { (\#86) }\end{array}$ & nisto (S. latus?) & $\begin{array}{c}19 \\
(\mathrm{CL} 6.7) \\
\end{array}$ & $280-300 \mathrm{~m}$ \\
\hline I & $\begin{array}{c}29 / 03 / 2004 \\
17: 00\end{array}$ & $\begin{array}{c}\text { Sicilian Channel - Gulf of Gela } \\
\varphi \mathrm{N} 37^{\circ} 02^{\prime} .27 ; \lambda \text { E } 14^{\circ} 06^{\prime} .71(\# 72)\end{array}$ & juvenile & $\begin{array}{c}30 \\
(\mathrm{CL} 9.3)\end{array}$ & $15-25 \mathrm{~m}$ \\
\hline $\mathrm{J}$ & $\begin{array}{c}29 / 03 / 2004 \\
17: 00\end{array}$ & $\begin{array}{c}\text { Sicilian Channel - Gulf of Gela } \\
\varphi \mathrm{N} 37^{\circ} 02^{\prime} .27 ; \lambda \mathrm{E} 14^{\circ} 06^{\prime} .71(\# 72)\end{array}$ & juvenile & $\begin{array}{c}22 \\
(\mathrm{CL} 7.9) \\
\end{array}$ & $15-25 \mathrm{~m}$ \\
\hline $\mathrm{K}$ & $\begin{array}{c}02 / 10 / 2004 \\
09: 15\end{array}$ & $\begin{array}{c}\text { Sicilian Channel - Pozzallo } \\
\varphi \mathrm{N} 36^{\circ} 23^{\prime} .11 ; \lambda \mathrm{E} 14^{\circ} 48^{\prime} .92(\# 85)\end{array}$ & nisto & $\begin{array}{c}18 \\
(\mathrm{CL} 6.7)\end{array}$ & $125-130 \mathrm{~m}$ \\
\hline $\mathrm{L}$ & $\begin{array}{c}04 / 10 / 2003 \\
08: 00\end{array}$ & $\begin{array}{c}\text { Sicilian Channel - Maltese Bank } \\
\varphi \mathrm{N} 36^{\circ} 03^{\prime} .07 ; \lambda \mathrm{E} 15^{\circ} 15^{\prime} .53 \text { (\#88) }\end{array}$ & nisto & $\begin{array}{c}25 \\
(\mathrm{CL} 7.9)\end{array}$ & $140-185 \mathrm{~m}$ \\
\hline M & $\begin{array}{c}22 / 11 / 2005 \\
06: 15\end{array}$ & $\begin{array}{c}\text { Southern coast of Sicily } \\
\varphi \mathrm{N} 37^{\circ} 07^{\prime} .83 ; \lambda \mathrm{E} 13^{\circ} 41^{\prime} .25(\# 45)\end{array}$ & juvenile & $\begin{array}{c}26 \\
(\mathrm{CL} 7.5)\end{array}$ & $30 \mathrm{~m}$ \\
\hline
\end{tabular}

survey, in fact earlier in the same day (haul C088), one nisto (L, $25 \mathrm{~mm}$ TL) with clearly pigmented pleuras (probably already in the reptant phase) was collected at 140-180 m depth, in a "soft bottom" community characterized by a high abundance of the anthozoan Alcyonium palmatum Pallas, 1766 and the crab Latreillia elegans Roux, 1830.

In 2005, 3 nisto/early juveniles were collected on 2 occasions: a double catch in shallow waters $(15-25 \mathrm{~m})$ in the spring (I, $30 \mathrm{~mm} \mathrm{TL}$; and J, $22 \mathrm{~mm} \mathrm{TL}$ ) and a single specimen $(\mathrm{K}, 18 \mathrm{~mm} \mathrm{TL})$ in the autumn on deeper waters (125-130 m)

Another early juvenile (M, $26 \mathrm{~mm}$ TL) was fished in 2005 at $30 \mathrm{~m}$ depth on rocky bottoms (in fact, the haul A045 had to be interrupted due to grasping). Finally, a very small phyllosoma instar (f, $16 \mathrm{~mm}$ TL) was collected in 2006 in the middle of the narrowest part of the Sicilian Channel on deep bottoms (haul 023, 430-500 m), unluckily in battered conditions. 

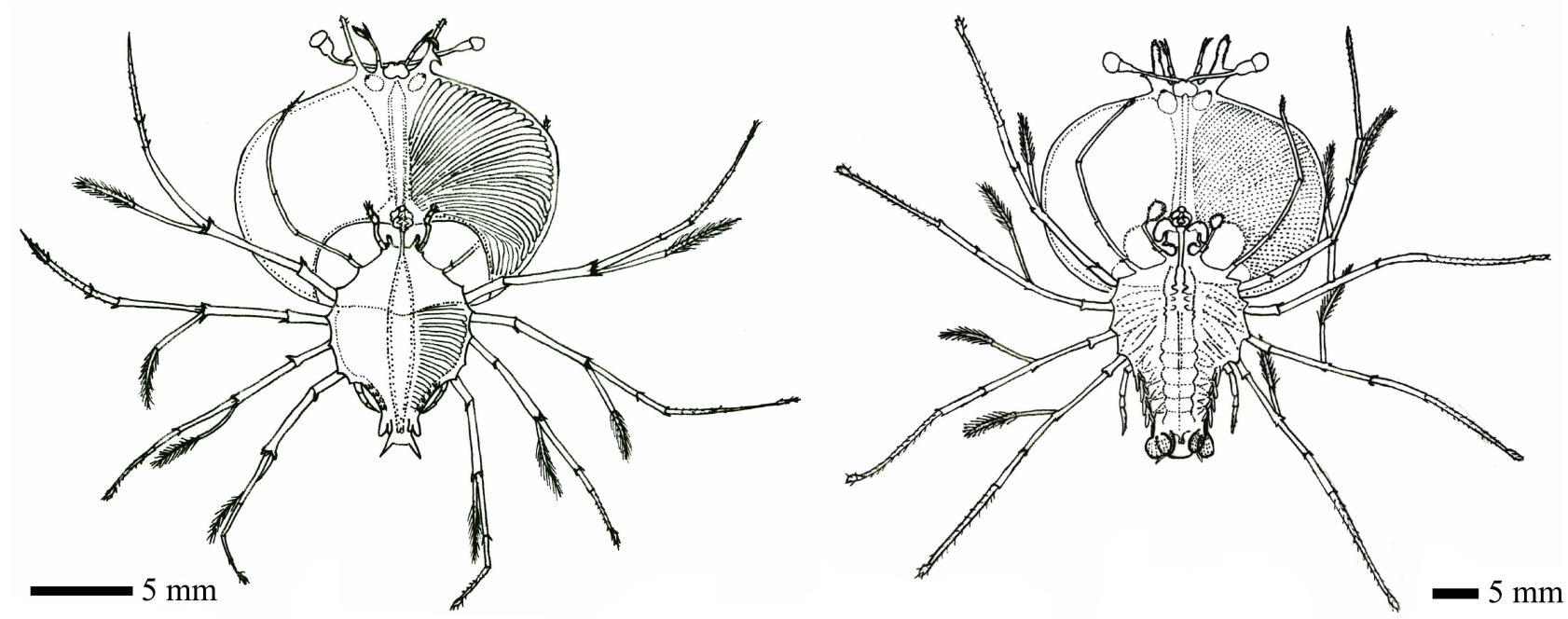

Fig. (3). Ventral view of two Scyllaridae phyllosoma instars (left, specimen e, from the Sicilian Channel, TL 16.3 mm; right, specimen c, from the Strait of Messina, TL $44.0 \mathrm{~mm}$ ).

Matter-of-factly, many naupliosomas and early phyllosoma instars of Scyllarides latus were obtained in aquaria from berried females [18], as well as phyllosomas of Scyllarus arctus by Gattelli [19] and Fernández et al. [20].

All phyllosoma instars, stranded or fished, were at the advanced stages of development, with well-formed abdomen and evident gills through the transparent body. The cephalic shields were oblong, with a ratio of circa 0.8 between length and width (CSL/CSW). The eyestalks were slightly longer than antennulae, which were as long as antennae. Different sizes and morphological features suggested that the phyllosoma instars caught in autumn 2003 and 2006 should be in an earlier stage of development than those stranded in winter. These results agree with Santucci [11], who reported that early phyllosoma instars of Scyllarus arctus (or at least the species recognized as such at that time) were found in summer while more advanced ones were collected in winter months. Still, determining the precise stage of development is difficult if not impossible, because many authors disagree on the discriminating features [12]. Even the size ranges proposed in literature [10] are too broad, overlapping and uneven to be useful, e.g. TL= 7-17 $\mathrm{mm}$ for instar $6,9-20$ $\mathrm{mm}$ for instar 7, 18-23 $\mathrm{mm}$ for instar 8 or $17-28 \mathrm{~mm}$ for instar 9. In fact, apart of the intrinsic divergence that may exist in case the two phyllosoma instars belong to different genera, the differences of one "early" instar (Fig. 3, left) when compared to a "late" instar (Fig. 3, right) are evident, as exemplified by the following descriptions:

Phyllosoma from the Sicilian Channel (autumn 2003) specimen $\mathrm{e}$ - possible instar VIII or IX.

$\mathrm{TL}=16.3 \mathrm{~mm} ; \mathrm{EL}=4.2 \mathrm{~mm} ; \mathrm{CSL}=10.6 \mathrm{~mm} ; \mathrm{CSW}=$ $13.7 \mathrm{~mm} ; \mathrm{CSL} / \mathrm{CSW}=0.77 ; \mathrm{TW}=7.0 \mathrm{~mm}$.

Antennae: forked, outer branch present as a stout spine, inner branch lightly longer than antennulae. Second maxilla: small unarmed bud. First maxilliped: present as a tiny bud adjacent to the second maxilla and very rudimental. Second maxilliped: of 4 articles. Third maxilliped: long, of 5 articles. Pereiopod 5: of 3 articles and about $1 / 2$ length of abdomen. Abdomen: forked uropods; telson with convex edge and two postero-lateral spines.
Phyllosoma from the Strait of Messina (winter 1996) specimen $\mathrm{c}$ - possible instar XI or XII

$\mathrm{TL}=44.0 \mathrm{~mm} ; \mathrm{EL}=9.8 \mathrm{~mm} ; \mathrm{CSL}=25.4 \mathrm{~mm} ; \mathrm{CSW}=33.4$ $\mathrm{mm} ; \mathrm{CSL} / \mathrm{CSW}=0.76 ; \mathrm{TW}=16.4 \mathrm{~mm}$.

Of a size larger than the largest Mediterranean phyllosoma instars reported in the literature. Antennae: forked, flat and considerably broader than in the previous specimen; the inner branch, sub-equal with antennulae. Second maxilla: bud flat, unarmed and large with wide anterior and posterior lobes. First maxilliped: bud unarmed, developed with distinct anterior and posterior lobes. Second maxilliped: with distally directed exopod bud. Third maxilliped: similar to second maxilliped. Pereiopod 5: of 4 articles. Abdomen: uropods flattened, leaf-like; telson with convex membrane similar to uropods. Gill buds on the legs. ${ }^{1}$

The absence of complete references on the larval taxonomic characteristics of the family Scyllaridae, necessary for distinguishing the different genera (Scyllarus and Scyllarides, small or large slipper lobsters, or the extremely rare Acantharctus) and species inhabiting the Mediterranean, did not allow attributing the phyllosoma instars to a specific taxon with certainty. In fact, Scyllarus arctus is the most common slipper lobster of the Mediterranean, and so should be its larval stages; still, phyllosomas e (shown left in Fig. 3) and f (not shown) present features not corresponding to cultured $S$. arctus larvae, such as the relative proportion of telson vs. pereiopod 5 (i.e., pereiopods are too short). In contrast, nistos and early juveniles may be identified, on the basis of the similarities of their antennae with the antennal morphology of the adults, as pertaining to the genera Scyllarus or Scyllarides, but the examined morphological characters were ineffective to discriminate between Scyllarus arctus and Scyllarus pygmaeus (the only two known Central Mediterranean species).

\footnotetext{
${ }^{1}$ Given the complexity of the morphological determination of the species, the nistos/early juveniles collected in the Sicilian Channel were prepared for genetic testing, with total genomic DNA extraction; unluckily, the samples were destroyed before sequencing in a lab incident, and therefore a positive taxonomic classification is not possible anymore.
} 
Nisto from the Sicilian Channel (autumn 2003) - specimen $\mathrm{L}: \mathrm{TL}=25 \mathrm{~mm} ; \mathrm{CL}=7.9 \mathrm{~mm} ; \mathrm{CW}=7.7 \mathrm{~mm}$

Carapace: slightly longer than wide, depressed and smooth, rostrum short and rounded, with a dorsal tubercle, gastric tooth, a pair of cardiac tubercles and posteriorly other scattered, indistinct tubercles; a crenate carina in the branchial zone ( 9 tuberculate teeth) and in the orbital zone (4 tuberculate teeth); at the lateral edge of carapace, acute spines are directed anteriorly; posterior edge of carapace with fringe of setae. Antennulae: inner flagellum more slender and flexible than outer one. Antennae: margin with 6 rounded teeth fringed by setae, thus belonging to the genus Scyllarus. Sternum: fairly flat. Pereiopod 1 short and robust, pereiopod 3 long and unarmed. Abdomen: posterior margin of terga 1-4 with $\mathrm{V}$-shaped median notch, of 1-5 with a fringe of setae; terga smooth.

The nisto specimen $\mathrm{H}(\mathrm{TL}=19 \mathrm{~mm} ; \mathrm{CL}=6.7 \mathrm{~mm}$; $\mathrm{CW}=$ $6.2 \mathrm{~mm}$ ) closely resembles the other nistos, but the lobes of the antennae are not visible, nor the lateral spine of the carapace. It is not known when the systematic characters appear and stabilize, whether suddenly after the phyllosoma/nisto passage or during the first few molts; still, given that a smooth antennal margin is a taxonomic discriminant feature, the nisto could belong to the species Scyllarides latus [notwithstanding that the capture in deep waters may suggest otherwise].

Finally, the 3 early juveniles all show lobes on the antennal margin, which sets them in the genus Scyllarus; still, it is difficult, if not impossible, to assign them to a specific taxon, because the other characteristics are in transition between those of $S$. arctus and $S$. pygmaeus. Nevertheless, given the depth of capture, there is a possibility that all of them belong to the very common and shallower species, $S$. arctus.

Recently, Palero et al. [21] were able to discriminate, via DNA analysis, the nistos of the two Central Mediterranean species, and described some differing morphological features; the nisto $(G)$ stranded near Messina presented at least one character (antennae with marked, long indentations) pertaining to the description of the Scyllarus arctus nisto. The same characters were not as easily seen in all the specimens from the Sicilian Channel (moreover, both Scyllarus species, differing in size as adults, have nistos of similar dimensions); however, the depth at which they settled suggested that one (L), and maybe both ( $\mathrm{H}$ too, if the antennal margin is not a species determinant), of the nistos fished in 2003 may have belonged to the deeper species Scyllarus pygmaeus. In contrast, the early juveniles (I, J, M) could perhaps be ecologically recognized as Scyllarus arctus. Incidentally, the taxonomic results of Palero et al. [21] may require changing the specific name from Scyllarus pygmaeus (Bate, 1888) to Scyllarus laevis (Sarato, 1885), since its larval form was described beforehand, as Nisto laevis.

Palero et al. [22] identified by molecular techniques a late-stage phyllosoma instar caught in deep water $(>200 \mathrm{~m})$ as Scyllarus pygmaeus. Its shape closely resembles that of the phyllosomas stranded near Messina, and even the size is similar for two of them; nevertheless, since the final-stage phyllosoma instar of Scyllarus arctus has not been described yet, a specific comparison is not possible. The phyllosoma instars collected in 2003 and 2006 were at an earlier stage of development (and ipso facto smaller), and therefore the description of Palero et al. [22] is not at all applicable; still, the depth at which they were caught lets to hypothesize that they also may belong to the species Scyllarus pygmaeus.

\section{CONFLICT OF INTEREST}

The authors confirm that this article content has no conflicts of interest.

\section{ACKNOWLEDGEMENTS}

Thanks to Dr Francesco Costa for the stranded specimens.

\section{REFERENCES}

[1] Falciai L, Minervini R. Guida dei Crostacei Decapodi d'Europa. Muzzio F, Ed. Padova, Italy 1992; 282.

[2] Bianchini ML, Greco S, Ragonese S. Il progetto "Valutazione della fattibilità e potenzialità del ripopolamento attivo per la magnosa, Scyllarides latus (Crostacei Decapodi)": sintesi e risultati. Biol Mar Mediterr 1998; 5(3): 1277-83.

[3] Forest J, Holtuis LB. The occurrence of Scyllarus pygmaeus (Bate) in the Mediterranean. Crustaceana 1960; 1: 156-63.

[4] Froglia C. Segnalazione di alcuni crostacei nuovi o rari per l'Adriatico. Quad Lab Technol Pesca Ancona 1979; 1: 43-52.

[5] Garcia Raso JE. Familia Scyllaridae Latreille 1825 (Crustacea, Decapoda) en la región sur-mediterranea española. Bol Asoc Esp Entomol 1982; 6(1): 73-8.

[6] Phillips BF, McWilliam MC. Phyllosoma and nisto stage of Scyllarus martensii Pfeffer (Decapoda, Scyllaridae) from the Gulf of Carpentaria, Australia. Crustaceana 1986; 51: 133-54.

[7] Robertson PB. The complete larval development of the sand lobster, Scyllarus americanus (Smith) (Decapoda, Scyllaridae), in the laboratory, with note on larvae from the plankton. Bull Mar Sci 1968; 18: 294-342.

[8] Ito M, Lucas JS. The complete larval development of the scyllarid lobster, Scyllarus demani Holthuis, 1946 (Decapoda, Scyllaridae), in the laboratory. Crustaceana 1990; 58(2): 144-67.

[9] McWilliam PS, Phillips BF, Kelly S. Phyllosoma larvae of Scyllarus species (Decapoda, Scyllaridae) from the shelf waters of Australia. Crustaceana 1995; 68(5): 537-66.

[10] Stephensen K. Decapoda Macrura (excl. Sergestidae). Rep Dan Oceanogr Exped Mediterr 1923; 2: 1-252.

[11] Santucci R. Contributo allo studio dello sviluppo post embrionale degli "Scyllaridaea" del Mediterraneo. II Scyllarus arctus (L.). III Scyllarides latus Latr. R. Comitato Talassogr Italiano 1925; Mem. CXXI: 1-17.

[12] Pessani D, Mura M. The biology of the Mediterranean scyllarids. In: "The biology and fisheries of the slipper lobsters". Crust Issues USA: CRC Press 2007; vol. 17: pp. 263-86.

[13] Rivera J, Mujica A. Larvas phyllosoma (Decapoda, Palinuridae y Scyllaridae) de la isles oceanicas chilenas. Invest Mar Valparaiso 2004; 32(2): 99-111.

[14] Spanier E, Lavalli KL. First record of an early benthic juvenile likely to be that of the Mediterranean slipper lobster, Scyllarides latus (Latreille, 1802). Crustaceana 2013; 86(3): 259-67.

[15] Webber WR, Booth JD. Larval stages, developmental ecology and distribution of Scyllarus sp. Z (probably Scyllarus aoteanus Powell, 1949) (Decapoda: Scyllaridae). NZ J Mar Freshw Res 2001; 35: 1025-56.

[16] Sekiguchi H, Booth JD, Webber WR. Early life history of slipper lobsters. Crust Issues. USA: CRC Press 2007; vol. 17: pp. 69-90.

[17] Fielder U, Spanier E. Occurrence of larvae of Scyllarus arctus (Crustacea, Decapoda, Scyllaridae) in the eastern Mediterranean preliminary results. Ann Istrian Mediterr Stud 1999; 17: 153-8.

[18] Bianchini ML, Ragonese S. In ovo embryonic development of the Mediterranean slipper lobster, Scyllarides latus. Lobster Newslett 2003; 16(1): 10-2. 
[19] Gattelli R. Studio del ciclo biologico di Scyllarus arctus (L. 1758) (Crustacea, Macrura) allevato in cattività. Italy: Tesi di laurea, DBES, University of Bologna 1-85; 1997.

[20] Fernández L, García C, Alborés I. Morphological changes in the larval development of the lesser slipper lobster Scyllarus arctus. Proceedings of the "9th Larval Biology Symposium", Wellington: (NZ), 2010.
[21] Palero F, Guerao G, Clark PF, Abelló P. The true identities of the slipper lobsters Nisto laevis and Nisto asper (Crustacea: Decapoda: Scyllaridae) verified by DNA analysis. Invert Syst 2009; 23: 77-85.

[22] Palero F, Guerao G, Abelló P. Morphology of the final stage phyllosoma larva of Scyllarus pygmaeus (Crustacea: Decapoda: Scyllaridae), identified by DNA analysis. J Plankton Res 2008; 30(4): 483-8.

Received: February 19, 2013

Revised: April 04, 2013

Accepted: April 11,2013

(C) Pagliarino et al.; Licensee Bentham Open.

This is an open access article licensed under the terms of the Creative Commons Attribution Non-Commercial License (http://creativecommons.org/licenses/by$\mathrm{nc} / 3.0 /$ ), which permits unrestricted, non-commercial use, distribution and reproduction in any medium, provided the work is properly cited. 